\title{
LIX. A new, easy, and cheap method of separating copper from silver
}

\section{Goetling}

To cite this article: M. Goetling (1805) LIX. A new, easy, and cheap method of separating copper from silver, Philosophical Magazine Series 1, 21:84, 352-353, DOI: $10.1080 / 14786440508676729$

To link to this article: http://dx.doi.org/10.1080/14786440508676729

曲 Published online: 18 May 2009.

Submit your article to this journal

Џ Article views: 2

Q View related articles $\asymp$ 
LIX. A new, easy, and cheap Method of separating Copper from Silver. By M. GoetLing*.

Four methods are known for separating copper from silver, in all of which the alloy is dissolved in the nitric acid. As the price of this acid is high, M. Goetling, in place of it, employs sulphuric acid, which is much cheaper. His process, which has fully answered his expectation, is as follows :

The proportion of silver in the alloy is first to be ascertained by the touch, or in any other way. For each part of silver one part of sulphuric acid, and for each part of copper three and three-fifth parts of the same acid, are to be taken. The acid, diluted with half its weight of water, is to be poured into the matrass on the alloy, reduced to small pieces. An addition of one part more of the acid to every sixteen parts of the alloy facilitates the solution. Place the matrass in a sand heat, and bring the contents to a state of ebullition. If care be taken to stir it frequently with a glass rod, the alloy will be broken down and cenverted into a sulphate in two or three hours. It will become thick, and sometimes hard. While still hot, six or eight times its weight of boiling water is to be added to it, and the heat to be continued for some time. By this means the sulphate will be dissolved, and a great part of the sulphate of silver will be precipitated. When the whole is found to be completely dissolved, a clean plate of copper, or a few pieces of clean copper money tied loosely in a coarse cloth, is suspended in the fluid, and the boiling is continued for some hours, by which means all the sulphate of silver is decomposed, and the metal separated in a metallic form.

To ascertain when the separation is complete, a small quantity of the solution is taken out and tried, by adding a few drops of a solution of muriate of soda. If a curdly precipitate is formed, it is a proof that some of the silver still remains in it; in which case the boiling must be continued.

When a complete separation is effected, the clear solution is to be decanted off with care, and the precipitate washed. To ascertain that all adhering sulphate of copper is removed, drop into the water last poured off from the precipitate a few drops of liquid ammonia. If any of that sulphate be

- From Tascben Bucb fur Skeidekunstler, \&c. 1804. 
still present, the ammonia will produce a blue colour in the water. The silver; f not wished to be kept as a powder, may be melted with from a fourth to a half of its weight of nitrate of potash.

The liquid sulphate of copper decanted from the precipitate, as also the water employed in washing it, may afterwards be evaporated in a copper bason, and, by crystallization, a quantity of blue vitriol equivalent to the cost of the acid will be obtained.

Should some parts of the alloy, by accident, have remained undissolved, they may be separated by decantation, and reserved for the next repetition of the process.

LX. Short Account of Travels between the Tropics, by Messrs. Humboldt and Bonpland, in 1799, 1800, 1801, 1802, 1803, and 1804. By J. C. DelameTHERIE*.

$\mathrm{T}$ HE interest which the learned world so justly takes in the travels of Messrs. Humboldt and Bonpland, as well as my friendship for them, impose on me the agreeable obligation of giving an abstract of what $I$ have been. able to learn respecting them, either from their public and private correspondence, or from the memoirs read in the Institute. This account will be short, but correct.

After making physical researches for eight years in Germany, Poland, England, France, Swisserland, and Italy, M. Humboldt came to Paris in 1798, where the Museum of Natural History afforded him an opportunity of making a voyage round the world with captain Baudin. When on the point of setting out for Havre, with Alexander-Aimé Goujou Bonpland, a pupil of the School of Medicine and Garden of Plants, the war which recommenced with Austria, and the want of funds, induced the Directory to put off the voyage of Baudin till a more favourable occasion. M. Humboldt, who since 1792 had conceived the design of undertaking, at his own expense, a voyage to the tropics, in order to promote the physical sciences, resolved then to accompany the men of science who were destined for Egypt. The battle of Aboukir having interrupted all direct communication with Alexandria, his plan was to take advantage of a Swedish frigate which was to carry the consul Seziolde-

* From Fournal de Pbysique, Thermidor, an 12.

Vol. 21; No. 84, May 1805. Z 